\title{
Spray penetration into asparagus (Asparagus officinalis L.) canopy using different nozzle inclinations and application rates
}

\author{
Penetración de la pulverización dentro del dosel del espárrago (Asparagus officinalis L.) usando \\ diferentes inclinaciones de boquilla y tasas de aplicación
}

\author{
Vásquez-Castro, J. $\left({ }^{1}\right)^{*}$; Ancco, A. $\left({ }^{2}\right)$; La Torre, B. $\left({ }^{3}\right)$ \\ *Corresponding author: jaque@lamolina.edu.pe \\ https://orcid.org/0000-0003-3407-6938
}

\begin{abstract}
Asparagus (Asparagus officinalis L.) is a difficult crop to treat with spraying pesticides because its architecture makes it difficult for droplets to penetrate inside of the canopy, where its pests are located. This study aims to examine the influence of operational parameters, such as nozzle inclination and application rates on the inner side of the canopy. We installed nozzles in the spray boom and its droplegs in three different inclinations: $0^{\circ}$ with the plant, $30^{\circ}$ in the direction of movement of the tractor-sprayer assembly $\left(+30^{\circ}\right)$, and $30^{\circ}$ in the opposite direction $\left(-30^{\circ}\right)$. We applied the mixture in application rates of 600,900 , and $1,200 \mathrm{~L} \mathrm{ha}^{-1}$. More so, the regulation used by the farmer of $0^{\circ}$ and $800 \mathrm{~L} \mathrm{ha}^{-1}$ was applied as a control. Copper $(\mathrm{Cu})$ was used as a tracer for the mixture in a dose of $13.5 \mathrm{~g} \mathrm{ha}^{-1}$. Also, non-plasticized polyvinyl chloride grooved tubes (PVC) were installed inside the asparagus canopy and polyethylene sheets were placed on the pipes at different heights from the ground. Later, we analyzed the sheets with atomic absorption spectrophotometry. Results showed that the nozzle inclination and sampling height had notable effects on the copper deposit. Conversely, different application rates showed no varied effects significantly. The greatest copper deposition in the asparagus canopy was achieved with a nozzle inclination of $+30^{\circ}$ with any application rate. Finally, we recommend regulating the sprayers with a nozzle inclination of $+30^{\circ}$ and an application rate of $600 \mathrm{~L} \mathrm{ha}^{-1}$ as the most effective adjustment for the distribution of pesticides and represent the lowest cost of operation since there is no influence of the application rate.
\end{abstract}

Key words: Sprayer, nozzle, pesticide, application technology, deposition

\section{Resumen}

El espárrago (Asparagus officinalis L.) es un cultivo muy difícil de tratar con plaguicidas vía aspersión, pues la arquitectura de la planta dificulta la penetración de las gotas en el dosel, en cuyo interior se localizan las principales plagas del cultivo. El objetivo del presente trabajo fue evaluar la influencia de los parámetros operacionales, tales como, el volumen de aplicación e inclinación de las boquillas sobre el depósito de la pulverización al interior del dosel del espárrago. Las boquillas fueron instaladas en la barra de pulverización y en los bajantes en una de las tres inclinaciones estudiadas, $0^{\circ}$ en relación a la planta, $30^{\circ}$ en sentido al desplazamiento del conjunto tractor-pulverizador $\left(+30^{\circ}\right)$ y $30^{\circ}$ en sentido opuesto $\left(-30^{\circ}\right)$. Las tasas de aplicación estudiadas fueron 600, 900 y $1200 \mathrm{~L} \mathrm{ha}^{-1}$. Además de esos tratamientos, se estudió la regulación empleada por el productor de $0^{\circ}$ y $800 \mathrm{~L} \mathrm{ha}^{-1}$. Para el tratamiento del cultivo fue usado el cobre (Cu) como trazador, en la dosis de $13,5 \mathrm{~g} \mathrm{ha}^{-1}$. Tubos ranurados de policloruro de vinilo no plastificado (PVC) fueron instalados al interior del dosel de la planta. Láminas de polietileno fueron acondicionadas sobre los tubos de PVC a diferentes alturas en relación al suelo. Después de la aplicación, las láminas de polietileno fueron analizadas mediante técnica de espectrofotometría de absorción atómica. Hubo efecto significativo de la inclinación de boquilla y de la altura de muestreo sobre el depósito de cobre. Por otro lado, no hubo efecto significativo del volumen de aplicación sobre el depósito. La mayor deposición de cobre al interior del dosel de la planta se consiguió con la inclinación de boquillas de $+30^{\circ}$ en cualquiera de los volúmenes de aplicación. Al no existir influencia del volumen de aplicación en el depósito de la pulverización al interior del dosel del espárrago, se recomienda regular los pulverizadores con inclinación de boquillas de $+30^{\circ}$ y volumen de aplicación de $600 \mathrm{~L} \mathrm{ha}^{-1}$ por ser la regulación más eficaz en la distribución de los plaguicidas y que a su vez representa el menor costo de operación.

Palabras clave: Pulverizador, boquilla, pesticida, tecnología de aplicación, deposición

\footnotetext{
${ }^{1}$ Universidad Nacional Agraria La Molina, Faculty of Agronomy. Entomology Department, Av. La Molina s/n, Lima 12, Peru.

${ }^{2}$ Universidad Nacional Agraria La Molina, Faculty of Agronomy. Lima, Peru.

${ }^{3}$ Universidad Nacional Agraria La Molina, Faculty of Agronomy. Soils Department. Lima, Perú.
} 


\section{Introduction}

Peru is one of the main asparagus (Asparagus officinalis L.) exporters of the world, reaching a planted area of 33,870 ha in 2015 (Ministerio de Agricultura y Riego [Minagri], 2020). The coastal agroecosystem and the efficient management of this crop have allowed high yields in the past years (Camborda et al., 2015). However, in recent years, the yield has reduced considerably among other factors due to severe pest attacks and flaws in control strategy, especially in chemical control (Ortega et al., 2014). This scenario has led to the reduction of crop areas in the country (Apaza et al., 2019). The effectiveness of the restraint of phytosanitary problems of asparagus, such as Prodiplosis longifila Gagné (Diptera: Cecidomyiidae) and Stemphilium spp, depends on choosing the adequate product, time application, and the distribution of the spray on the plant.

The use of pesticides as the only containment measure and the inadequate regulation of sprayers have caused serious problems to the asparagus production.

Due to the flaws in pest control, producers have increased the dose and number of applications per season, causing problems related to resistance and pesticide residues (Vásquez-Castro, 2012, 2013). Asparagus is generally sown in lines separated by $1.5 \mathrm{~m}$, and at their greatest development can grow up to $1.6 \mathrm{~m}$ in height, $1.3 \mathrm{~m}$ in width, and creates a dense foliage that is a favorable microclimate to pests. Consequently, this hinders the spray penetration to the asparagus canopy.

More so, horizontal spray boom with vertical section adaptations (droplegs) is recommended for herbaceous crops of notable height, as this equipment manages to spray the top and sides of the asparagus (Knott, 1987). Nevertheless, a low spray penetration rate is seen in the asparagus canopy, mainly in the lower third of the plant, preferred place of $P$. longifila and Stemphilium spp. (Scodellaro, 1995; Castillo, 2019). Conversely, high application rates are widely used to enhance the application quality for pest control; but the results have not been satisfactory. Good results have been obtained in other crops when nozzles were fitted with inclination angles over the spray boom (Panisson et al., 2004; Foqué \& Nuyttens, 2011). Nevertheless, negative results are known (Zhu et al., 2002). However, some reports in international literature showed that low application rates result in higher pesticide deposits and lower operation costs (Véliz et al., 2010; Sánchez-Hermosilla et al., 2013; Cunha, Victor, \& Sales, 2018).

There is little scientific information about application technology in asparagus crops. Thus, in this study, we evaluate the influence of some operational parameters, nozzle inclination, and application rates on the pesticide deposit in the asparagus canopy.

\section{Materials and Methods}

The fieldwork was done in a commercial production farm of green asparagus, variety UC-157, located at the Ica valley (south Coast of Peru). The plants were at the second sprouting stage (1.6 m of height, $1.3 \mathrm{~m}$ canopy-width and dense foliage). A mounted sprayer (Jacto Brand, Condor $600^{\circledR}$ model) was used for the application of the mixture. The sprayer was equipped in a $13.5 \mathrm{~m}$ long horizontal spray boom, eight droplegs at $1.5 \mathrm{~m}$ apart, and 59 empty conejet nozzles (Teejet Brand, TXVK-10 ${ }^{\circledR}$ model) (Figure 1). To avoid the pressure being an influencing variable for the nozzles drops spectrum, all the treatments were performed at a working pressure of $1,000 \mathrm{kPa}$ and this resulted in an average flow of $1.17 \mathrm{~L} \mathrm{~min}^{-1}$. This way, the different application rates used $(600,800,900$, and 1,200 $\mathrm{L} \mathrm{ha}^{-1}$ ) were obtained through travel speed regulation of the tractor-sprayer assembly, keeping the tractor engine rotation at 1,700 RPM, providing 540 RPM in the power takeoff. The travel speeds were 5.1, 3.8, 3.4, and $2.6 \mathrm{~km} \mathrm{~h}^{-1}$ for the application rates of $600,800,900$, and 1,200 $\mathrm{L} \mathrm{ha}^{-1}$, respectively.

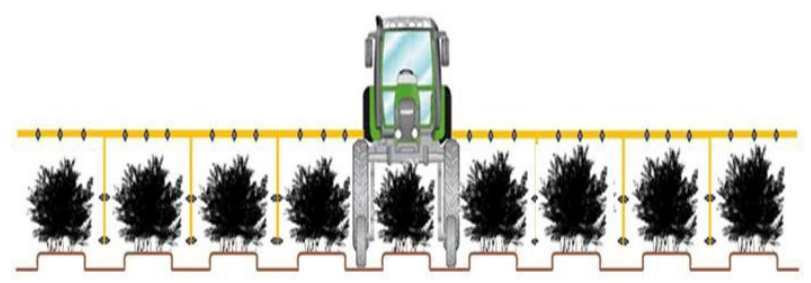

Figure 1. The scheme of the tractor-sprayer assembly used in the experiment. Notice the horizontal spray boom, the droplegs, and the nozzles distribution.

The nozzles were installed in the horizontal spray boom and the droplegs in one of the following three inclination angles: $0^{\circ}$ with the plant, $30^{\circ}$ in the direction of displacement from the tractor-sprayer assembly $\left(+30^{\circ}\right)$, and $30^{\circ}$ in the opposite direction $\left(-30^{\circ}\right)$. In addition to those treatments, we applied the regulation used by the farmer, nozzle on $0^{\circ}$, and an application rate of $800 \mathrm{~L} \mathrm{ha}^{-1}$, as control. More so, we used copper as a tracer with a dose of $13.5 \mathrm{~g} \mathrm{ha}^{-1}$ for the crop treatment. For the evaluation of the mixture deposit in the asparagus canopy, we used the methodology proposed by Travis et al. (1985), and Pergher et al. (1999) with some modifications. PVC tubes of $3 / 4 "$ diameter and $1.68 \mathrm{~m}$ long were installed inside the canopy, simulating the stem of the plants. Polyethylene sheets of $0.14 \times 0.16 \mathrm{~m}$ were placed above the tubes at different heights from the ground $(0.04-0.18 ; 0.26-0.40 ; 0.48-0.62$; $0.70-0.84 ; 0.92-1.06 ; 1.14-1.28 ; 1.36-1.50 \mathrm{~m})$. These sheets served as collectors of surface droplets containing copper (Figure 2). The sheets were collected and examined by atomic absorption spectrophotometry to quantify the copper deposition (ppm) after the application. In total, we applied ten treatments that corresponded to three nozzles inclination with three application rates each and one control treatment (regulation used by the farmer). 


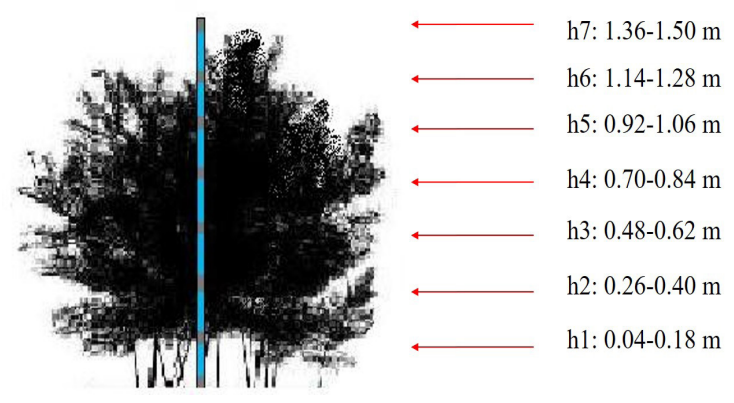

Figure 2. The PVC tube installed inside the asparagus canopy. Notice the polyethylene sheets placed at different heights from the ground (h1-h7).
Table 1. Analysis of variance of copper deposit by a mixed model for repeated measurements.

\begin{tabular}{llll}
\hline Origin of variation & d.f. & $\mathrm{F}$ & $\mathrm{Pr}>\mathrm{F}$ \\
\hline Treatment & 9 & 51,32 & $<0,0001$ \\
Control $\times$ other treatments & 1 & 66,39 & $<0,0001$ \\
Nozzle tilt angle & 2 & 178,49 & $<0,0001$ \\
Application rate & 2 & 8,02 & 0,0007 \\
$\begin{array}{l}\text { Nozzle tilt angle } \times \text { application } \\
\text { rate }\end{array}$ & 4 & 5,61 & 0,0005 \\
$\begin{array}{l}\text { Sampling height } \\
\text { Treatment } \times \text { sampling height }\end{array}$ & 6 & 29,30 & $<0,0001$ \\
\hline
\end{tabular}

Table 2. Copper deposit means (ppm) in function to treatments and sampling height.

\begin{tabular}{|c|c|c|c|c|c|c|c|c|}
\hline \multirow{2}{*}{$\begin{array}{l}\text { Nozzle tilt } \\
\text { angle }\end{array}$} & \multirow{2}{*}{$\begin{array}{l}\text { Application } \\
\text { rate }\left(\text { Lha }^{-1}\right)\end{array}$} & \multicolumn{7}{|c|}{ Height (h) } \\
\hline & & h1 & h2 & h3 & h4 & h5 & h6 & h7 \\
\hline $0^{\circ}$ & 600 & $0,124^{\mathrm{d}}$ & $0,096^{\text {bc }}$ & $0,048^{\mathrm{cd}}$ & $0,038^{\mathrm{c}}$ & $0,039^{c}$ & $0,041^{\mathrm{c}}$ & $0,043^{\mathrm{cd}}$ \\
\hline $0^{\circ}$ & 800 & $0,078^{\mathrm{d}}$ & $0,062^{\mathrm{c}}$ & $0,024^{\mathrm{d}}$ & $0,016^{\mathrm{c}}$ & $0,007^{\mathrm{c}}$ & $0,010^{\mathrm{c}}$ & $0,010^{\mathrm{d}}$ \\
\hline $0^{\circ}$ & 900 & $0,110^{\mathrm{d}}$ & $0,059^{c}$ & $0,034^{\mathrm{d}}$ & $0,022^{\mathrm{c}}$ & $0,026^{\mathrm{c}}$ & $0,022^{\mathrm{c}}$ & $0,028^{\mathrm{cd}}$ \\
\hline $0^{\circ}$ & 1200 & $0,098^{d}$ & $0,092^{\mathrm{bc}}$ & $0,043^{\text {cd }}$ & $0,011^{\mathrm{c}}$ & $0,006^{\mathrm{c}}$ & $0,014^{c}$ & $0,023^{\text {cd }}$ \\
\hline$-30^{\circ}$ & 600 & $0,152^{\mathrm{cd}}$ & $0,063^{\mathrm{c}}$ & $0,046^{\mathrm{cd}}$ & $0,042^{\mathrm{c}}$ & $0,042^{\mathrm{c}}$ & $0,048^{\mathrm{bc}}$ & $0,103^{\mathrm{bc}}$ \\
\hline$-30^{\circ}$ & 900 & $0,320^{\mathrm{b}}$ & $0,172^{b}$ & $0,126^{\mathrm{bc}}$ & $0,132^{\mathrm{ab}}$ & $0,136^{\mathrm{ab}}$ & $0,134^{\mathrm{ab}}$ & $0,136^{\mathrm{ab}}$ \\
\hline$-30^{\circ}$ & 1200 & $0,229^{c}$ & $0,143^{\mathrm{bc}}$ & $0,103^{\text {bcd }}$ & $0,066^{\text {bc }}$ & $0,080^{\mathrm{bc}}$ & $0,086^{\mathrm{abc}}$ & $0,100^{\mathrm{bc}}$ \\
\hline$+30^{\circ}$ & 600 & $0,360^{\mathrm{b}}$ & $0,334^{\mathrm{a}}$ & $0,187^{\mathrm{ab}}$ & $0,159^{\mathrm{a}}$ & $0,133^{\mathrm{ab}}$ & $0,140^{\mathrm{a}}$ & $0,207^{\mathrm{a}}$ \\
\hline$+30^{\circ}$ & 900 & $0,476^{\mathrm{a}}$ & $0,318^{\mathrm{a}}$ & $0,237^{a}$ & $0,217^{\mathrm{a}}$ & $0,211^{\mathrm{a}}$ & $0,161^{\mathrm{a}}$ & $0,159^{a b}$ \\
\hline$+30^{\circ}$ & 1200 & $0,324^{b}$ & $0,297^{\mathrm{a}}$ & $0,229^{\mathrm{a}}$ & $0,168^{\mathrm{a}}$ & $0,198^{\mathrm{a}}$ & $0,161^{\mathrm{a}}$ & $0,174^{\mathrm{ab}}$ \\
\hline
\end{tabular}

Different letters in columns represent significant differences in a t-test $(\mathrm{p} \leq 0.05)$.

Furthermore, for each treatment, we installed nine PVC tubes distributed in different parts of the experimental plot, which had an area of $810 \mathrm{~m}^{2}(60 \mathrm{~m} \times 13.5 \mathrm{~m})$. We analyzed the deposition data with repeated measures design by considering the treatment effects, the sampling height, and the interaction between them. We also applied an F-test for orthogonal contrasts by considering that the treatments were arranged in the $3 \times 3$ factorial scheme with an additional treatment and the t-test for the contrasts in which we observed a notable effect at $5 \%$ level of the F-test. Finally, using the mixed process of SAS (1999) software, we analyzed the data.

\section{Results and Discussion}

The variance analysis (F-test) showed a notable effect related to the treatment and sampling height (Table 1). The four orthogonal contrasts used for the splitting of the treatment were also significant, including the interaction of nozzle tilt angle $\times$ application rate. The interaction between treatment and sampling height was not noticeable, which indicated that the effects of the treatments were independent of the sampling height. However, we decided to detail the analysis of these two factors because the effects of the treatments and sampling height were significant (Table 2).

The results showed in Table 2 demonstrated that the treatments with $+30^{\circ}$ nozzle tilt angle had higher deposits in the inner part of the canopy, followed by the $-30^{\circ}$ nozzle tilt angle treatment with an application rate of 900 $\mathrm{L} \mathrm{ha}^{-1}$. The smallest deposits occurred generally in the treatments with $0^{\circ}$ nozzle tilt angle. The regulation used by the farmer $\left(0^{\circ}\right.$ y $\left.800 \mathrm{~L} \mathrm{ha}^{-1}\right)$ had a very low copper deposit values in all the sampling heights. The quantity of copper deposited in the inner canopy with the regulation used by the farmer was seven times lower than the treatment of $600 \mathrm{~L} \mathrm{ha}^{-1}$ of application rate and $+30^{\circ}$ nozzle tilt angle. These results explained the flaws found in the control of key pests, such as P. longifila and Stemphylium spp., that in later years have caused huge economic loses. These pests show colonizing preference for the inner third-inferior asparagus canopy, which is the place of difficult access to spraying. The $+30^{\circ}$ nozzle tilt angle probably increased the area of exposition of the jet to the plant surface, which together with the turbulence generated by the air resistance to the trajectory of the droplets favored their penetration, mainly for the thirdinferior part of the plant. The travel speed of the tractor-spray assembly did not influence 
the results. As per each nozzle inclination, no statistical differences among the different application rates obtained with different travel speeds were seen. Similarly, da Cunha et al. (2018) showed that the travel speed did not influence the deposit of pesticides in soybean crops. Flaws in the control of other pests of asparagus and problems related to their pesticide resistance in Peru were known in the literature (Bustillo, 2009; Vásquez-Castro, 2012).

An inadequate regulation of the sprayers likely increased the incidence of these problems. Generally, there were no notable differences in the deposition of the pesticide in different application rates. So, for pest control, it is indifferent to apply $600,800,900$, and $1,200 \mathrm{~L} \mathrm{ha}^{-1}$; however, the greatest economic benefit for the farmer will be achieved with the lower application rates, where lower operational cost in oil and labor is considered. Contrastingly, the timing of the pest control plays an important role as per large plantations. Therefore, the faster the application, the greater the probability of success in controlling the pest, which can be achieved with lower application rates. Interestingly, this study is the first to be performed in the field of pesticide application technology in Peru and one of the few studies related to asparagus crop worldwide. Consequently, we advise for more research as per finding the most efficient pesticide applying method for a crop as important and complex as asparagus.

\section{Conclusions}

The nozzle tilt angle of $30^{\circ}$ in the direction of movement of the tractor-spray assembly provides a large deposit of the pesticide inside the asparagus canopy.

The application rate does not influence the pesticide deposit. Finally, increasing the volume of water for the pulverizations does not enhance the coverage or the deposition of substances in the asparagus crops.

\section{References}

Apaza, W., Quiroz, P., \& Julca-Otiniano, A. (2019). Characterisation of avocado and asparagus farms in the Chavimochic irrigation project in La Libertad, Peru. Peruvian Journal of Agronomy, 3(3), 91-103. http://dx.doi.org/10.21704/pja.v3i3.1342

Bustillo, A. (2009). Evaluación de insecticidas químicos y biológicos para controlar Frankliniella occidentalis (Thysanoptera: Thrypidae) en cultivos de espárrago. Revista Colombiana de Entomología, 35(1), 12-17. http://www.scielo.org.co/scielo.php?script $=$ sci arttext\&pid=S0120-04882009000100003\&lng $=$ en $\& n r m=$ iso

Camborda, F., Castillo, J., \& Rodríguez, S. (2015). Trampas de luz con panel pegante para la captura de adultos de Prodiplosis longifila Gagné (Diptera: Cecidomyiidae) en el cultivo de espárrago. Ecología Aplicada, 14(2), 139-145 http://www.scielo.org. pe/scielo.php?script $=$ sci_arttext\&pid $=$ S 1726 22162015000200006\&lng=es\&tlng=es

Castillo, J. (2019). Desarrollo de un Programa de Manejo Integrado de Plagas para Espárrago (Asparragus officinalis L.) en la Irrigación de Chavimochic. [Doctoris Phillosophiae thesis, Universidad Nacional Agraria la Molina]. La Molina Repository. http://repositorio.lamolina.edu.pe/bitstream/ handle/UNALM/3758/castillo-valiente-jorgeramon.pdf? sequence $=1 \&$ isAllowed $=y$

da Cunha, J., Victor, A., \& Sales, C. (2018). Spray deposition on soybean crop using different travel speeds and application rates. Engenharia Agricola, 38(1), 82-87. http://dx.doi.org/10.1590/18094430-Eng.Agric.v38n1p82-87/2018

Foqué, D., \& Nuyttens, D. (2011). Effects of nozzle type and spray angle on spray deposition in ivy pot plants. Pest Management Science, 67(2), 199-208. https://doi.org/10.1002/ps.2051

Knott L. (1987). Spraying equipment for different plant protection treatments in asparagus. Gesunde Pflanzen, 39, 19-23.

Ministerio de Agricultura y Riego. (2020). Serie de estadísticas de producción agrícola (SEPA). Espárrago - Superficie cosechada. [Data set] http:// frenteweb.minagri.gob.pe/sisca/?mod=salida

Panisson, E., Boller, W., \& Reis, E. (2004). Avaliação da deposição de calda em anteras de trigo, para o estudo do controle químico de giberela (Gibberella zeae). Engenharia Agrícola, 24(1), 111-120. https://doi. org/10.1590/S0100-69162004000100013

Pergher, G., Zucchiatti, N., \& Gubiani, R. (1999). Influence of spray application parameters on deposition in an asparagus crop. Journal of Agricultural Engineering Research, 73(1), 19-28. https://doi. org/10.1006/jaer.1998.0386

Ortega, E., Ureta, C., Mayanga, A., Morey, G., Graterol, L., Dyer, P., \& Mialhe, E. (2014). Identificación molecular de la mosquilla del brote Prodiplosis sp. Gagné en los cultivos de Asparagus officinalis L. por amplificación parcial del gen citocromo oxidasa I. Idesia, 32(4), 29-41. http://dx.doi.org/10.4067/ S0718-34292014000400005

Sánchez-Hermosilla, J., Páez, F., Rincón, V. J., \& PérezAlonso, J. (2013). Volume application rate adapted to the canopy size in greenhouse tomato crops. Scientia Agricola, 70(6), 390-396. https://doi. org/10.1590/S0103-90162013000600003 
SAS Institute. (1999). SAS/STAT User's guide 8.0. Cary, 1999. Toolbox. CD - ROM.

Scodellaro, M. (1995). Asparagus: Defense strategies for the control of Stemphylium and Fusarium. Informatore Agrario, 51, 39-41.

Travis, J., Sutton, T., \& Skroch, W. (1985). A technique for determining the deposition of heavy metals in pesticides. Phytopathology, 75(7), 783-785. https:// www.apsnet.org/publications/phytopathology/ backis sues / D ocuments / 1985 Articles/ Phyto75n07_783.PDF

Vásquez-Castro, J. A. (2012). Resistencia a insecticidas en poblaciones peruanas de Spodoptera frugiperda procedentes de campos de Espárrago. Proceedings of the 58th ISTH Annual Meeting Interamerican Society for Tropical Horticulture, 9, La Molina, Lima.

Vásquez-Castro, J. A. (2013). Residuo de plaguicidas en el ambiente. Revista Agronomía, 50, 36-45.

Véliz, R., Gadanha Jr, C., \& Vásquez-Castro, J. (2010). Eficiencia de dos sistemas para la aspersión de plaguicidas en árboles de cítricos. Revista Colombiana de Entomología, 36(2), 217-222. http://www.scielo.org.co/scielo.php?script=sci arttext\&pid=S0120-04882010000200007\&lng=en $\&$ nrm $=$ iso

Zhu, H., Rowland, D. L., Dorner, J. W., Derksen, R. C., \& Sorensen, R. B. (2002). Influence of plant structure, orifice size, and nozzle inclination on spray penetration into peanut canopy. Transactions of the ASAE, 45(5), 1295-1301. http://doi. org/10.13031/2013.11058 